\title{
Penggunaan Notifikasi Berbasis Android untuk Memantau Perawatan pada Sistem Otomasi Akuaponik Menggunakan Mikrokontroller ATmega 2560
}

\author{
Indri Neforawati; Dinabilah Adani; Eka Rahmawati; Ayu Fitriana \\ Jurusan Teknik Informatika dan Komputer \\ Politeknik Negeri Jakarta, Indonesia \\ indri.neforawati@tik.pnj.ac.id, dibilaadani@gmail.com, ekarahmawt@g mail.com, ayfian62@gmail.com
}

Diterima: 12 September 2016. Disetujui: 28 Oktober 2016. Dipublikasikan: Nope mber 2016

\begin{abstract}
Abstrak - Permasalahan masyarakat di kotakota besar saat ini adalah sulitnya melakukan perawatan terhadap tanaman yang saat ini mulai ditanam menggunakan sistem akuaponik. Maraknya fenomena penggunaan smartphone di masyarakat perkotaan, serta penerapan mikrokontroler dalam bidang pertanian menjadikan sebuah sistem notifikasi berbasis smartphone untuk memonitoring sistem akuaponik mampu menjadi solusi yang baik untuk mengatasi permasalahan tersebut. Tujuan dibuatnya sistem adalah untuk memudahkan perawatan sistem akuaponik sehingga masyarakat perkotaan tertarik untuk bertani dengan mengoptimalisasi penggunaan smartphone dan mikrokontroller sebagai teknologi yang populer saat ini. Metode yang digunakan untuk membangun sistem adalah metode Waterfall. Keuntungan menggunakan aplikasi ini, pengembangan dan daur ulang sistem akan menjadi lebih mudah dan terarah. Setelah proses pengujian sistem, dapat disimpulkan bahwa sistem yang telah terbangun $80 \%$ ini mampu mengirimkan notifikasi pada kondisikondisi yang telah ditentukan.
\end{abstract}

Kata Kunci: smartphone, notifikasi, telegram, akuaponik

\section{PENDAHULUAN}

Fenomena penggunaan internet yang marak di kota-kota besar me mberikan manfaat kemudahan dalam hal informasi kepada masyarakat kota tersebut. Kemudahan ini dapat digunakan untuk melakukan kontrol perawatan tanaman dan ternak. Menurut data presentase rumah tangga yang pernah mengakses internet yang dikeluarkan oleh Badan Pusat Statistik, pada tiga bulan terakhir tahun 2014 sekitar 50,53\% masyarakat perkotaan mengakses internet. Metode pertanian kota yang saat ini sedang dikembangkan dan digemari oleh masyarakat adalah sistem pertanian akuaponik yang dapat dilakukan pada lahan sempit seperti di perkotaan. Konsep pertanian akuaponik yaitu dengan menanam tanaman pada pot-pot kecil kemudian diletakkan pada pipa besar yang telah dilubangi seukuran pot agar air sisa penyiraman yang menetes dari pot dapat dialirkan ke kolam yang diletakkan dibawahnya, untuk digunakan kembali sebagai air kolam ikan juga dipakai untuk menyiram tanaman. Selain penghematan air, akuaponik juga mengoptimalkan pemanfaatan lahan untuk pertanian.

Hal ini sejalan dengan Peraturan Mentri Pertanian Republik Indonesia NOMOR 19/Permentan/HK.140/4/2015 tentang Rencana Strategis Kementerian PertanianTahun 2015-2019, Laju konversi lahan produktif ke penggunaan nonpertanian mencapai 100 ribu hektar per tahun. Lahan pertanian yang semakin sempit tentu akan mempengaruhi ketahanan pangan masyarakat. Akuaponik merupakan metode yang tepat untuk membantu meningkatkan ketahan pangan masyarakat, khususnya dalam keluarga dengan melakukan pertanian secara mandiri. Dengan akuaponik, setiap keluarga memiliki lahan pertanian dan peternakan kecil dengan memanfaatkan pekarangan rumah untuk sedikitnya membantu memenuhi kebutuhan pangan keluarga, serta memanfaatkan ketersediaan air seminimal mungkin sehingga mengurangi dan menghemat penggunaan air dan membantu meningkatkan ketahanan pangan keluarga.

Meksipun model pertanian kota akuaponik dapat digunakan sebagai alenatif bercocok tanam dan berternak ikan pada lahan yang kecil dan sempit, namun yang kemudian menjadi masalah adalah masyarakat saat ini tidak memiliki banyak waktu untuk memerhatikan bahkan merawat tanaman yang ada di halaman rumah sekalipun. Pekerjaan yang banyak menyita waktu membuat masyarakat kota sulit untuk memerhatikan tanaman dan ternak ikan di pertanian. Sedangkan kurangnya perawatan akan mengakibatkan tanaman yang telah ditanam dan ternak ikan tidak terurus lalu ke mudian mati. 
Dengan me mbuat sistem otomasi penyiraman dan pengontrol air kolam yang dapat di-monitoring melalui notifikasi yang dikirim via internet melalui aplikasi Whatsapp, proses perawatan tanaman dan kolam ikan diharapkan akan menjadi lebih mudah. Sistem yang saat ini banyak diterapkan pada pertanian konvensional dan akuaponik sebelumnya tidak mengontrol air sisa hasil penyiraman dan mengirim notifikasi ke individu masyarakat. Karena diterapkan pada metode akuaponik, maka dibutuhkan sistem yang tidak hanya mengontrol proses penyiraman tanaman, namun juga dapat mengontrol aliran air ke kolam dan menjaga kejernihannya, serta memberikan notifikasi mengenai status tanaman dan pengairan.

Penelitian sebelumnya[1] hanya membahas mengenai pengairan dan sumber kelistrikannya. Penelitian ini menitik beratkan pada fungsi kontrol air untuk memudahkan perawatan dan pengairan serta penggunaan kembali air sisa penyiraman, sehingga proses perawatan tanaman dan kolam pada metode akuaponik menjadi lebih mudah.

\section{TINJAUAN PUSTAKA}

Dalam penerapannya, sistem akuaponik masih dilakukan secara manual dan terdapat beberapa kendala yang biasanya terjadi dalam penerapan sistem akuaponik, diantaranya adalah : teknologi yang digunakan masih secara manual, tidak terdapat alat yang mampu me-monitoring kondisi tanaman maupun ikan secara tepat waktu, pengendali penyiram tanaman masih manual tidak berdasarkan kebutuhan kelembaban tanah, tidak ada sistem yang mengontrol ketinggian level air pada kolam ikan, tidak terdapat sistem filtering untuk meminimalisir keracunan pada ikan dari adanya sistem sirkulasi air dari tanaman, serta penggunaan ju mlah pompa yang cukup banyak.

Dilihat dari kendala-kendala tersebut, diperlukan teknologi terbaru untuk memudahkan penerapannya sehingga dapat membantu masyarakat dalam bercocok tanam dan membudi dayakan ikan dengan memanfaatkan perangkat mobile berbas is Android. Penelitian ini menggunakan teknologi mikrokontroller ATM 2560, penggunaan modul wifi ESP8266-01, dan teknologi notifikasi terbaru berbasis Android ke aplikasi Telegram yang akan lebih mempermudah pengguna dalam memon itoringnya.

\section{A. Smartphone}

Menurut Gayatri (2011), smartphone adalah sebuah telepon seluler dengan fungsi menyerupai komputer. Di dalamnya terdapat fasilitas kamera, email, dan organizer. Fitur penting yang membedakan smartphone dengan ponsel biasa adalah aplikasi untuk meningkatkan pemrosesan data dan konektivitas [2].

\section{B. Sistem Operasi}

Haryanto (2012) menyatakan bahwa pengertian sistem operasi secara umum ialah pengelola seluruh sumber daya yang terdapat pada sistem komputer dan menyediakan sekumpulan layanan (sistem calls) ke pemakai sehingga mempermudah dan menyamankan penggunaan serta pemanfaatan sumber daya sistem ko mputer[3].

\section{Android}

Rasjid (2010) menyatakan bahwa Android adalah software untuk perangkat mobile yang mencakup sistem operasi, middleware dan aplikasi kunci. Pengembangan aplikasi pada platform Android menggunakan bahasa pemrograman Java. Serangkaian aplikasi inti Android antara lain email, program SMS, kalender, peta, browser, kontak, dan lain-lain. Android berbasis pada versi Linux 2.6 untuk layanan sistem inti seperti keamanan, manajemen memori, manajemen proses, network stack, dan model driver. Terdapat dua jenis distributor sistem operasi Android di dunia yaitu pertama yang mendapat dukungan penuh dari Google atau Google Mail Services (GMS) dan kedua adalah yang benar-benar bebas distribusinya tanpa dukungan langsung Google atau dikenal sebagai Open Handset Distribution (OHD) [4].

\section{Notifikasi}

Bersumber dari informasi yang dimuat dalam situs[5], dinyatakan bahwa notifikasi atau yang dalam bahasa Indonesia dikenal dengan pemberitahuan adalah sebuah pesan yang dikirim oleh server terpusat pada device endpoint. Berdasarkan cara pengirimannya, notifikasi dibagi menjadi dua jenis, yaitu push notification dan pull notification. Notifikasi yang digunakan dalam penelitian ini adalah push notification, dimana informasi dikirimkan oleh aplikasi perangkat lunak kepada computing device tanpa request spesifik dari pengguna.

\section{E. Telegram}

Berdasarkan dari sumber yang di muat di halaman situs Telegram.org[6], dinyatakan bahwa Telegram adalah aplikasi pesan chat yang berfokus pada keamanan dan kecepatan yang super cepat, sederhana dan gratis. Pengguna dapat menggunakan Telegram di semua perangkat pada waktu yang sama dan tersinkronisasi di sejumlah ponsel, tablet atau ko mputer.

Telegram menggunakan teknologi cloud message, sehingga pengguna dapat mengakses pesan dari beberapa perangkat sekaligus, termasuk tablet dan komputer, dan sharing file yang tidak terbatas 
dari foto, video dan file (doc, zip, mp 3, dll) hingga 1,5 GB. Dan jika pengguna tidak ingin menyimpan data pada perangkatnya, pengguna dapat tetap menyimannya di cloud. Dengan infrastruktur ini, Telegram lebih cepat dan lebih aman. Selain itu, Telegram gratis dan akan tetap bebas dari iklan, tidak ada biaya berlangganan, selamanya.

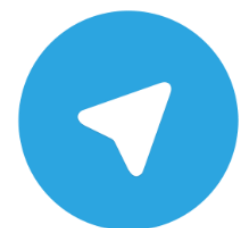

Gambar 1. Logo Aplikasi Telegram

API Telegram bersifat Open source, dan telegram menyambut developers untuk menciptakan aplikasi Telegram mereka sendiri. Telegram juga memiliki API Bot, platform untuk developers yang memungkinkan orang dengan mudah membangun tools untuk Telegram.

\section{F. Mikrokontroller}

Oktariawan (2013) menyatakan bahwa mikrokontroler adalah sistem mikroprosesor lengkap yang terkandung di dalam sebuah chip. Mikrokontroler berbeda dari mikroprosesor serbaguna yang digunakan dalam sebuah PC, karena sebuah mikrokontroler umumnya telah berisi komponen pendukung sistem minimal mikroprosesor, yakni memori dan pemrograman Input-Output. Mikrokontroler dapat di program untuk melakukan penghitungan, menerima input dan menghasilkan output. Mikrokontroler mengandung sebuah inti prosessor, memori dan pemrograman Input-Output[7].

\section{G. Arduino Mega 2560}

Oktariawan (2013) menyatakan bahwa, Arduino Mega 2560 (ATMega 2560) adalah suatu mikrokontroler pada ATMega 2560 yang mempunyai 54 input/output digital yang mana 16 pin digunakan sebagai PWM keluaran, 16 masukan analog, dan di dalamnya terdapat $16 \mathrm{MHZ}$ osilator kristal, koneksi USB, power, ICSP, dan to mbol reset. Kinerja Arduino ini memerlukan dukungan mikrokontroler dengan menghubungkannya pada suatu komputer dengan kabel USB untuk menghidupkannya menggunakan arus AC atau DC dan bisa juga dengan menggunakan baterai[7].

\section{H. Sensor Kelembaban Tanah (Soil Moisture Sensor)}

Pamungkas (2010) menyatakan bahwa sensor kelembaban tanah atau dalam istilah Bahasa Inggris soil moisture sensor adalah jenis sensor kelembaban yang mampu mendeteksi intensitas air di dalam tanah (moisture)[8].

Sensor ini berupa dua lempengan konduktor berbentuk pisau berbahan logam yang sangat sensitif terhadap muatan listrik dalam suatu media khususnya tanah. Kedua lempengan logam tersebut merupakan media yang menghantarkan tegangan listrik yang nilainya relatif kecil berkisar antara 3,3 volt dan baru tegangan tersebut akan diubah menjadi tegangan digital untuk diproses lebih lanjut oleh sistem[8].

\section{Sensor Ultrasonik HC-SRO4}

Nugraha (2015) menyatakan bahwa, Sensor Ultrasonik HC-SR04 adalah sebuah modul yang berfungsi untuk melakukan pengukuran jarak suatu benda/ halangan dengan memanfaatkan sinyal suara ultrasonik. Performa yang stabil, akurasi yang tinggi dan harga yang murah merupakan kelebihan dari sensor ini sehingga banyak dipakai dalam berbagai aplikasi pengukuran jarak[9].

Pin yang tersedia pada modul ini yaitu pin VCC, TRIG, ECHO dan GND. VCC dihubungkan dengan pin $5 \mathrm{v}$ pada arduino, pin GND dihubungkan dengan pin GND, PIN ECHO dan pin TRIGGER dihubungkan dengan pin digital yang ada di Arduino.

\section{J. Sensor Cahaya (LDR)}

Karim (2013) menyatakan bahwa, Sensor LDR merupakan salah satu jenis resistor yang dapat mengalami perubahan resistansi apabila mengalami perubahan penerimaan cahaya. Besarnya nilai hambatannya tergantung pada besar-kecilnya cahaya yang diterima oleh LDR itu sendiri. Resistansi LDR pada tempat yang gelap biasanya mencapai sekitar $10 \mathrm{M} \Omega$, dan ditempat terang turun menjadi sekitar $150 \Omega$. Seperti halnya resistor konvensional, pemasangan LDR dalam suatu rangkaian sama persis seperti pemasangan resis tor biasa[10].

\section{K. $E S P-8266$}

Bersumber dari informasi yang dimuat dalam[11], ESP 8266 adalah wifi module dengan output serial TTL yang dilengkapi dengan GPIO. Wifi module ini dapat digunakan secara standalone maupun dengan mikrokontroler tambahan untuk kendalinya. Terdapat beberapa tipe dari ESP8266. Pada penelitian ini, yang digunakan adalah ESP8266-01. 


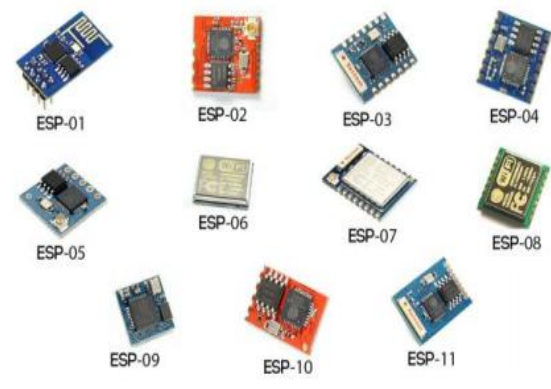

Gambar 2. Tipe-Tipe ESP8266

\section{Akuaponik}

Bersumber dari informasi yang dimuat pada situs[12] menuliskan bahwa, Aquaponik adalah perpaduan dua sistem yaitu "aquaculture" (budidaya ikan) dan hidroponik (menanam tanpa media tanah) yang diintegrasikan dalam satu kesatuan. Aquaponik juga memanfaatkan air sebagai media tanam namun perbedaan yang paling mencolok dengan hidroponik adalah aquaponik tidak me mbutuhkan nutrisi.

Wahap dkk. (2010) menyatakan pula, bahwa akuaponik adalah kombinasi akuakultur dan hidroponik yang bertujuan untuk memelihara ikan dan tanaman dalam satu sistem yang saling terhubung[13]. Dalam sistem ini, limbah yang dihasilkan oleh ikan digunakan sebagai pupuk untuk tanaman, kemudian air yang dialirkan dengan sistem resirku lasi dari media pemeliharaan ikan dibersihkan oleh tanaman sehingga dapat digunakan kembali oleh ikan[13].

\section{METODE PENGEMBANGAN SISTEM}

Pada Penelitian ini, metode pengembangan sistem yang digunakan adalah metode $\mathrm{W}$ aterfall. Hal ini dikarenakan penggunaan Waterfall dalam pembuatan sebuah sistem menjadikan pengembangan daur ulang sistem menjadi lebih jelas dan terarah. Metode ini memiliki beberapa tahapan diantaranya adalah seperti pada Gambar 3.

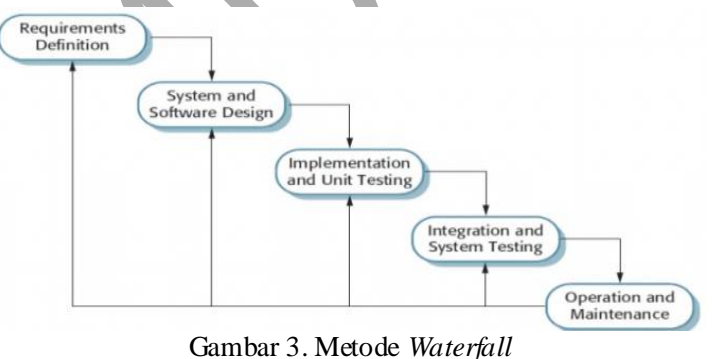

\section{A. System and Software Design}

Pada tahap ini, dibuat perancangan dari sistem yang dibuat baik perancangan alat (hardware) maupun program (software) yang akan digunakan. Tahapannya adalah:

a. Perancangan Sistem
Melakukan perancangan sistem sebagai penyelesaian masalah secara detail dan global, baik menggunakan diagram alir, diagram blok, dan pemilihan perangkat lunak dan perangkat keras yang akan digunakan dala $\mathrm{m}$ sistem.

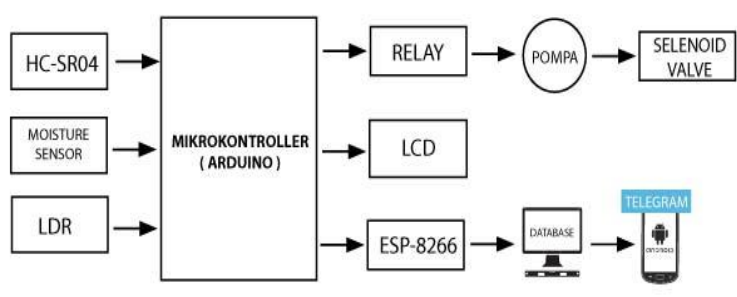

Gambar 4. Blok Diagram

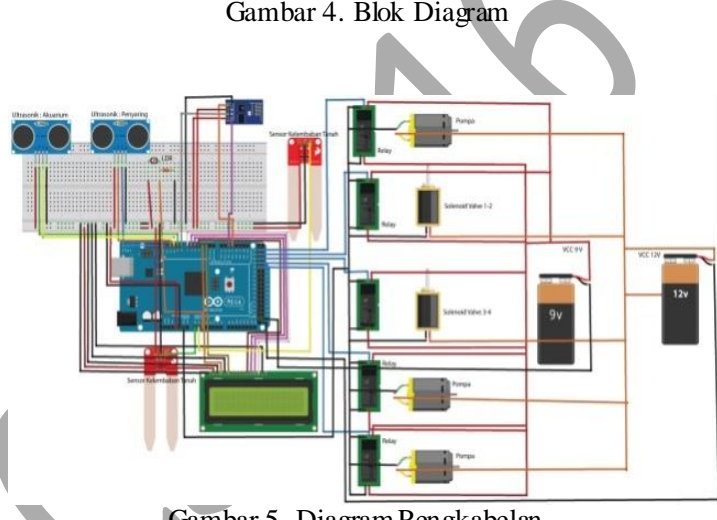

B. Implementation dan Unit Testing

Pada tahap ini, semua yang telah dirancang, diiimplementasikan sesuai hasil rancangan. Berikut adalah tahapannya:

a. Imple mentasi Sistem

Melakukan implementasi dan pembangunan sistem sebagai penyelesaian masalah, dengan membuat sistem notifikasi level air, sistem notifikasi penyiram tanaman, sistem notifikasi filter air.

b. Uji coba per sub sistem serta mengidentifikasi kesalahan-kesalahan dari setiap sub sistem.

C. Integration dan System Testing

Pada tahap ini, semua sub sistem saling diintegrasikan sehingga menjadi kesatuan sistem otomasi akuaponik. Dilakukan uji coba baik sistem hardware maupun software. Berikut adalah tahapannya adalah :

a. Integrasi

Melakukan integrasi dari sub sistem baik sistem hardware maupun software sehingga menjadi sistem notifikasi pada akuaponik.

b. Pengujian terhadap sistem yang telah diintegrasikan apakah telah bekerja sesuai yang diharapkan

\section{Operation and Maintenance}

Pada tahap ini, sistem akan dijalankan sesuai dengan kerja alat dan kerja sistem yang telah dibuat. 
Dilakukan pemeliharaan agar sistem tetap berjalan sesuai kerjanya. Tahapan yang dilakukan adalah:

a. Penggunaan Sistem yang terintegrasi

Sistem dijalankan, dimana hasilnya sesuai dengan kebutuhan dan tujuan sehingga sistem dapat digunakan sesuai kegunaannya.

b. Menjalankan sistem sesuai dengan kerja alat dan sistem serta melakukan perawatan sistem.

\section{HASIL DA N PEMBAHASAN}

Untuk menganalisis hasil kinerja sistem, perlu dilakukan pengujian terhadap sistem. Tujuannya adalah untuk melihat apakah fungsifungsi tersebut telah berjalan sesuai dengan tujuan yang diharapkan. Pengujian dilakukan terhadap hubungan mikrokontroller ke data base, serta sistem notifikasi menggunakan aplikasi Telegram-cli. Hasilnya dapat dilihat pada Tabel 1.

TABEL 1. DATA HASIL PENGUJIAN PENGUKURAN LEVEL AIR - TELEGRAM

\begin{tabular}{|c|c|c|c|c|c|}
\hline \multicolumn{3}{|c|}{$\begin{array}{c}\text { Data hasil “Surut” Pada } \\
\text { Database }\end{array}$} & \multicolumn{2}{c|}{$\begin{array}{c}\text { Data hasil “Surut” Pada } \\
\text { Telegram }\end{array}$} & \multirow{2}{*}{$\begin{array}{c}\text { Selisih } \\
\text { (Menit) }\end{array}$} \\
\hline Waktu & Status & Nilai & Waktu & Status & \\
\hline $\begin{array}{c}2016-08-13 \\
22: 36\end{array}$ & Surut & 7 & $\begin{array}{c}2016-08-13 \\
22: 38\end{array}$ & Surut & 2 \\
\cline { 1 - 4 } $\begin{array}{c}2016-08-13 \\
23: 49\end{array}$ & Surut & 8 & $\begin{array}{c}2016-08-13 \\
23: 49\end{array}$ & Surut & 0 \\
\hline $\begin{array}{c}2016-08-13 \\
23: 54\end{array}$ & Surut & 5 & $\begin{array}{c}2016-08-13 \\
23: 56\end{array}$ & Surut & 2 \\
\hline $\begin{array}{c}2016-08-13 \\
23: 54\end{array}$ & Surut & 5 & $\begin{array}{c}2016-08-13 \\
23: 56\end{array}$ & Surut & 2 \\
\hline
\end{tabular}

Berdasarkan data hasil yang diterima, menunjukkan bahwa notifikasi akan dikirimkan ke aplikasi telegram saat kondisi air surut. Dalam pengirimannya, waktu pengiriman sesuai dan terkadang terdapat selisih waktu pengiriman yang diterima ke aplikasi Telegram.

TABEL 2. HASIL PENGUKURAN KELEMBABAN TANAH TELEGRAM

\begin{tabular}{|c|c|c|c|c|}
\hline \multicolumn{2}{|c|}{$\begin{array}{l}\text { Data status "kering" } \\
\text { diterima database }\end{array}$} & \multicolumn{2}{|c|}{$\begin{array}{l}\text { Data status "kering" } \\
\text { diterimatelegram }\end{array}$} & \multirow{2}{*}{$\begin{array}{l}\text { Selisih } \\
\text { (Menit) }\end{array}$} \\
\hline Waktu & Status & Waktu & Status & \\
\hline $\begin{array}{c}2016-08-13 \\
23: 22\end{array}$ & Kering & $\begin{array}{c}2016-08-13 \\
23: 46\end{array}$ & Kering & 24 \\
\hline $\begin{array}{c}2016-08-13 \\
23: 49\end{array}$ & Kering & $\begin{array}{c}2016-08-13 \\
23: 50\end{array}$ & Kering & 1 \\
\hline $\begin{array}{c}2016-08-13 \\
23: 49\end{array}$ & Kering & $\begin{array}{c}2016-08-13 \\
23: 51\end{array}$ & Kering & 1 \\
\hline $\begin{array}{c}2016-08-13 \\
23: 54\end{array}$ & Kering & $\begin{array}{c}2016-08-13 \\
23: 56\end{array}$ & Kering & 2 \\
\hline
\end{tabular}

Berdasarkan pengujian aplikasi Telegram, data hasil pengujian menunjukkan bahwa data yang dikirimkan dengan selisih waktu yang cukup panjang dengan waktu saat data yang diterima oleh data base. Setelah dianalisa, disimpulkan bahwa hal tersebut terjadi disebabkan oleh tidak aktifnya penjadwalan crontab atau koneksi Arduino Mega 2560 ke data base server yang terputus menyebabkan data base tidak memperoleh data terbaru. Terputusnya koneksi Arduino Mega 2560 ke data base server juga menyebabkan pengiriman data yang sama dilakukan lebih dari satu kali pada menitmenit berikutnya disebabkan sistem tidak menemu kan data terakhir lain.

TABEL 3. HASIL PENGUKURAN TINGKAT KEJERNIHAN AIR-TELEGRAM

\begin{tabular}{|c|c|c|c|c|}
\hline \multicolumn{2}{|c|}{$\begin{array}{c}\text { Data status "kering" } \\
\text { diterima database }\end{array}$} & \multicolumn{2}{|c|}{$\begin{array}{c}\text { Data stat us "kering" } \\
\text { diterimatelegram }\end{array}$} & \multirow{2}{*}{$\begin{array}{c}\text { Selisih } \\
\text { (menit) }\end{array}$} \\
\hline Waktu & Status & Waktu & Status & \\
\hline $\begin{array}{c}2016-08-13 \\
23: 37\end{array}$ & Keruh & $\begin{array}{c}2016-08-13 \\
23: 38\end{array}$ & - & 1 \\
\hline $\begin{array}{c}2016-08-13 \\
23: 41\end{array}$ & Keruh & $\begin{array}{c}2016-08-13 \\
23: 43\end{array}$ & $\overline{\mathrm{h}}$ & 2 \\
\hline $\begin{array}{c}2016-08-13 \\
23: 41\end{array}$ & Keruh & $\begin{array}{c}2016-08-13 \\
23: 47\end{array}$ & $\bar{h}$ & 6 \\
\hline $\begin{array}{c}2016-08-13 \\
23: 50\end{array}$ & $\bar{K}$ & $\begin{array}{c}2016-08-13 \\
23: 51\end{array}$ & Keruh & 1 \\
\hline
\end{tabular}

Berdasarkan data hasil yang diterima, menunjukkan bahwa notifikasi yang terkirim ke aplikasi Telegram dikirimkan saat kondisi air pada kolam penyaringan air menunjukkan kondisi air keruh. Dalam pengiriman notifikasi, waktu pengiriman data ke sistem notifikasi terdapat selisih waktu yang diterima data base dengan waktu pada notifikasi Telegram, hal ini disebabkan penjadwalan yang dilakukan crontab tidak aktif atau koneksi Arduino Mega 2560 ke data base server yang terputus yang menyebabkan data base tidak me mperoleh data terbaru.

\section{KESIMPULAN DAN SARAN}

Berdasarkan hasil pengujian, dapat diambil kesimpulan bahwa sistem otomasi akuaponik bekerja dengan baik dan sesuai dengan kemampuan, dimana sensor level ketinggian air mampu membaca jarak aquarium di kisaran 0-36cm, sensor kelembaban tanah mampu membaca kelembaban tanah dengan kisaran 0-1023, serta sensor cahaya LDR dapat menangkap cahaya yang diterima di kis aran 0-1023.

Sistem notifikasi ke aplikasi Telegram berjalan dengan baik, dimana notifikasi diterima ketika terdapat kondisi yang diterima dari data base untuk dikirimkan ke notifikasi Telegram, apabila terdapat kondisi yaitu, air di akuarium menunjukan nilai $<10 \mathrm{~cm}$ air berada di kondisi surut, ke le mbaban tanah di kisaran 0-370 dengan kelembaban tanah kering, dan saat kondisi air di dalam penyaringan menunjukan hasil pembacaan sensor di kisaran $<400-899$ yang berarti air keruh.

Waktu pengiriman notifikasi dari data base ke aplikasi telegram juga menunjukkan jeda waktu yang tidak terlalu lama. Pengiriman notifikasi 
dilakukan selama 1 menit sekali dengan kondisi yang sudah ditentukan. Sistem Notifikasi pada otomasi akuaponik ini berbasis Android dan baru di implementasikan pada aplikasi Telegram. Akan lebih baik, jika sistem ini juga dikembangkan di aplikasi Android lainnya, berbasis iOS maupun web.

\section{REFERENSI}

[1] Ika P dan M Rifa'i. 2012. ]"VERTIQUAPONIK" Inovasi Lahan Sempit. Jurnal ELTEK, Vol 10 No 02.

[2] Gayatri. 2011. Women's Guide. Gagas Media.Jakarta.

[3] Haryanto, Edy Victor. 2012. Sistem operasi Konsep dan Teori.Edisi ke-1.ANDI.

[4] http://www.ubaya.ac.id/2014/content/articles detail/7/Andr oid--Sistem-Operasi-pada-Smart phone.html

[5] http://www.searchmobilecomput ing.techt arget.com, [Diakses Tanggal 20 Mei 2016

[6] Telegram.org [ diakses tanggal 30 Mei 2016 - 13:25 WIB]

[7] Oktariawan, Imran. Martinus. dan Sugiyanto. 2013. Pembuatan Sistem Otomasi Dispenser Menggunakan Mikrokontroler Arduino Mega 2560. Jurnal FEMA, Vol. 1,
Nomor 2. .[Diakses tanggal 11 November 2016 - 19:39 WIB].

[8] Pamungkas, H. Y. 2010. Monitoring Kelembaban Tanah dalam Pot Berbasis Mikrokontroler ATmega 168 dengan tampilan Output Situs jejaring sosial Twitter untuk pembudidaya dan penjual tanaman hias Anthurium. Institut Teknologi Sepuluh November, Surabaya. [Diakses tanggal 11 November 2016 - 19:50 WIB]

[9] Nugraha, Anggara Trisna. 2015. Rancang Bangun Teknologi Pemurni Air.Skripsi.Universitas Jember,Jember.[Diakses tanggal 27 Maret 2016 - 16:18 WIB]

[10] Karim, Syaiful. 2013. Sensor dan Aktuator. Kementerian Pendidikan dan Kebudayaan. Jakarta.

[11] Ricky,Ahmad.2016. SOMU-KEEP||SMART SOIL MOIST URE KEEPER.http://geeknesia.com/projects/somukeep-smart-soil-moist ure-keeper-.[Diakses tanggal $16 \mathrm{Mei}$ $2016-11: 52$ WIB]

[12] http://hidroponiq.com/2014/08/hidroponik-vs-aquaponik/

[13] Wahap, N., A. Estim., A.Y.S Kian., S. Senoo dan S. Mustafa. 2010. Producing Organic Fish and Mint in an Aquaponic System. Borneo Marine Research Institue, Sabah, Malaysia 